\title{
Genetic variability and association of traits in Ethiopian barley (Hordeum vulgare L.) genotypes at Holetta, Central Ethiopia
}

\author{
Tigist Shiferaw $^{1^{\star}} \bullet$ Berhanu Abate $^{2} \bullet$ Berhane Lakew $^{1}$
}

\author{
${ }^{1}$ Holetta Agricultural Research Center, P. O. Box 2003, Holetta, Ethiopia. \\ ${ }^{2}$ Hawassa University, School of Plant and Horticultural Sciences, P. O. Box 05, Hawassa, Ethiopia.
}

${ }^{*}$ Corresponding author. E-mail: tigistshiferaw92@gmail.com

Accepted $4^{\text {th }}$ January, 2020.

\begin{abstract}
Ethiopia is the secondary center for diversity of barley, and has a large number of accessions preserved in its gene bank. To determine the genetic variability and to assess the associations among morpho-agronomic characters, three hundred and twenty Ethiopian barley genotypes were evaluated in 2017 main-season at Holetta Agricultural Research Centre using $20 \times 16$ Alpha Lattice design. The analysis of variance showed that there were significant differences among the genotypes in all traits except for days to emergence, indicating the presence of genotypic variation among the studied genotypes. Out of 320 , one hundred and twenty three genotypes gave significantly higher yield than the grand mean $(2772.45 \mathrm{~kg} / \mathrm{ha})$ with yield advantage of best performing genotypes ranging between $145.98 \%$ for genotype Shege to $100.66 \%$ for genotype HB-1963. Grain yield, biomass yield and kernels per spike had high phenotypic and genotypic coefficients of variation. The estimates of broad sense heritability and genetic advance were high for days to heading and maturity and thousand kernels weight. Grain yield exhibited positive and highly significant correlations with days to heading and maturity, number kernels per spike, biomass yield, harvest index, thousand kernels and hectolitre weights. Path coefficient analysis revealed that biomass yield followed by seed harvest index had high and positive direct effects on grain yield and negative direct effect was exerted by days to heading and scald disease. Therefore, there is a high possibility of developing new varieties from these genotypes.
\end{abstract}

Keywords: Barley, character, genetic variability.

\section{INTRODUCTION}

Barley is the most important food crop domesticated about 7,000 BC from its wild relative, Hordeum vulgare ssp spontaneum, in the area of the Middle East known as the Fertile Crescent (Zohary and Hopf, 1993; Badr et al., 2000). Ethiopia was first considered as the center of origin for cultivated barley, although later it was regarded as a secondary center of diversity because of the absence of the wild relative (Vavilov, 1951).

Barley is the fourth most important cereal crop in the world after wheat, maize and rice (FAO, 2016), while in Ethiopia, it is fifth in yield (ton ha-1) after Teff, Maize,
Sorghum and Wheat with productivity of 2.16 ton ha-1 (CSA, 2018). Barley is a staple food grain, especially in the highlands of Ethiopia. It is used for food (bread, "injera"), beverages (local beer), livestock feed, and the straw are used for thatched roofing in the countryside of Ethiopia (USDA, 2015). Barley is grown twice a year from August to December (main season) and from March to July (short season) in altitudes from 1800 to 3400 m. a. s. I. (Berhane et al., 1996; Muluken, 2013).

Among cultivated cereals in Ethiopia, barley has a large number of accessions preserved in the Ethiopian gene 
Table 1. Zones, altitude ranges and number of accessions of the collected barley germplasm.

\begin{tabular}{lccccc}
\hline \multirow{2}{*}{ Altitude classes } & \multicolumn{5}{c}{} \\
\cline { 1 - 5 } Zone of collection & Class I & Class II & Class III & Class IV & \multirow{2}{*}{ Total } \\
\cline { 2 - 5 } & $<\mathbf{2 0 0 0}$ & $\mathbf{2 0 0 1 - 2 5 0 0}$ & $\mathbf{2 5 0 1 - 3 0 0 0}$ & $\mathbf{3 0 0 0}$ & \\
\cline { 1 - 5 } Agew Awi & 1 & 4 & 5 & - & 10 \\
Arsi & 6 & 4 & 10 & 5 & 25 \\
Bale & 5 & 5 & 6 & 3 & 19 \\
South Gondar & 1 & 5 & 5 & 4 & 15 \\
South wello & 1 & 6 & 10 & 2 & 19 \\
South Tigray & 5 & 8 & 10 & & 24 \\
Gurage & 2 & 5 & 12 & 8 & 27 \\
Hadya & 2 & 6 & 3 & - & 10 \\
Keficho Shekicho & 1 & 1 & - & - & 2 \\
West Shewa & 2 & 5 & 8 & 2 & 17 \\
East Gojam & - & 5 & 6 & 2 & 13 \\
East harerge & 1 & 6 & 6 & - & 13 \\
East Shewa & - & 1 & $\overline{5}$ & - & 1 \\
East Wellega & 1 & 10 & 6 & - & 16 \\
East Tigray & 4 & 8 & 15 & 3 & 20 \\
North Omo & 3 & 5 & 11 & 11 & 36 \\
North Shewa & 4 & 10 & - & - & 27 \\
Released varieties & - & - & 118 & 42 & 320 \\
Total & 39 & 94 & & & \\
\hline
\end{tabular}

bank, with over 15,300 samples. This is approximately $23 \%$ of the total landraces in the gene bank (Abebe, 2006). The large diversity of Ethiopian barley landraces could be due to the diversity in soils, climate, altitude and topography together with social and geographical isolation for long periods (Harlan, 1968). The wide ecological ranges of barley crop can generate a high potential for adaptive genetic diversity against abiotic and biotic stresses, which is an excellent genetic resource for crop improvement (Ellis et al., 2000; Nevo 1992).

Studying the genetic variability among the Ethiopian barley genotypes is crucial for developing high yielding varieties to satisfy the food demand of the increasing population in the highlands facing decrease in cultivated land. However, the conserved genotypes must be utilized for crop improvement in order to tackle the future global food and nutritional security challenges. Therefore, this study was conducted with the objectives of evaluating the genetic variability among Ethiopian barley genotypes and assessing the association among morpho-agronomic plant characteristics.

\section{MATERIALS AND METHODS}

The experiment was conducted at Holetta Agricultural Research Centre, which is located at $9^{\circ} 00^{\prime} \mathrm{N}$ and $38^{\circ} 30^{\prime}$ $\mathrm{E}$ at an altitude of $2400 \mathrm{~m}$ above sea level. Holetta Agricultural Research Centre has mean annual rainfall of
$1044 \mathrm{~mm}$, mean relative humidity of $60.6 \%$, and mean maximum and minimum temperatures of 22.10 and $6.20^{\circ} \mathrm{C}$, respectively. The soil of the experimental field is clay classified as Nitosol, which was characterized with $\mathrm{pH}$ of 6.2 .

\section{Experimental materials and design}

A total of 320 barley genotypes including 27 released varieties and 293 pure lines collected from the representative barley growing Zones of Ethiopia were used for the study (Table 1).

The experiment was laid out in $20 \times 16$ Alpha Lattice Design with two replications, and each plot consisted of four rows spaced $0.2 \mathrm{~m}$ with $2.5 \mathrm{~m}$ length. The seed rate was $85 \mathrm{~kg} \mathrm{ha}^{-1}$ and fertilizers were applied during planting in the form of Urea and Diamonium phosphate (DAP) at the rate of 41 and $46 \mathrm{~kg} \mathrm{ha}^{-1} \mathrm{~N}$ and $\mathrm{P}_{2} \mathrm{O}_{5}$ respectively. The experiment was planted on 2017 planting time commonly practiced by farmers in the district and all field management practices were handled as required.

\section{Data collection}

Crop phonology like days to emergence (DTE), days to heading (DTH) and days to maturity (DTM) were counted from date of planting to $50 \%$ seedling emergence and 
from date of emergence to $50 \%$ heading and $75 \%$ physiological maturity of plants in each plot respectively. The average plant height $(\mathrm{PH})$ was measured from the ground to the tip of spikes of five main plants of the two middle rows of each plot. Disease scoring on barley leaf scaled and net blotch disease was assessed by visual examination using a scale of 0 to 9 according to (Saari and Prescot, 1975). Yield components such as fertile tillers per plant (FTP), spike length per plant (SLP) and kernels per spike (KPs) were determined from five random plants of the middle rows of each plot. After harvesting, indiscriminately counted thousand kernels weight (TKW) from each plot were weighted and adjusted to $12.5 \%$ standard grain moisture content of cereals, while hector liter weight (HLW) was measured after drying the grain of each plot up to $12.5 \%$ moisture content. The total above ground biomass yield (BY) harvested from the middle two rows of each plot was dried out for some days under sun and then weighted. The grain yield (GY) was harvested from the middle two rows of each plot and adjusted to the standard grain moisture content (12.5\%).

\section{Analysis of variance (ANOVA)}

Data were analyzed by restricted maximum likelihood (REML) to fit a mixed model with Genotypes, Replications and Blocks within replication as random effects. The REML model produced best linear unbiased predictors (BLUPs), which is a standard method for estimating random effects of a mixed model. PROC MIXED was conducted to estimate genotypes as well as residual variance components. The analysis of variance of quantitative traits was done using the general linear model:

$$
Y_{i j k}=\mu+g_{i}+r_{j}+b_{k j}+\varepsilon_{i j k}
$$

Where $Y i j k=$ the response of $Y$ trait from the $i^{\text {th }}$ genotype, grown in the $k^{\text {th }}$ incomplete block of $j^{\text {th }}$ replicate, $\mu$ $=$ general mean, $g_{i}=$ random effect of the $i^{\text {th }}$ genotype, $r_{j}=$ random effect of the $j^{\text {th }}$ replicate, $b_{k j}=$ random effect of $k^{\text {th }}$ incomplete block in a $j^{\text {th }}$ replicate, $\varepsilon_{i j k}=$ experimental error.

\section{Phenotypic and genotypic variance and estimation of broad sense heritability}

The total phenotypic variance of each of the traits was partitioned into contributions due to genetic and nongenetic factors using the analysis of variance components method suggested by Singh and Chaudhury (1996). Genotypic variance and phenotypic variance were calculated as $\sigma^{2} g=\frac{\mathrm{MSg}-\mathrm{MSe}}{r}$ and $\sigma^{2} \mathrm{p}=\sigma^{2} \mathrm{~g}+\sigma^{2} \mathrm{e} / \mathrm{r}$ respectively, where $\mathrm{MS}_{\mathrm{g}}=$ mean squares of genotypes, $M S_{e}=$ mean squares of experimental error, $r=$ number of replications, $\sigma^{2} \mathrm{p}=$ phenotypic variance, $\sigma^{2} \mathrm{~g}=$ genotypic variance, and $\sigma^{2} 2_{\mathrm{e}}=$ error variance. Broad-sense heritability $\left(\mathrm{H}^{2}\right)$ is the proportion of phenotypic variance explained by genotypic variance. $\mathrm{H}^{2}=\frac{\delta^{2} \mathrm{~g}}{\delta^{2} \mathrm{p}} \times 100$.

\section{Estimation of phenotypic and genotypic coefficient of variation}

This is done using the following equations suggested by Singh and Chaudhury (1996).

$\mathrm{PCV}=\left(\sqrt{ } \sigma^{2} \mathrm{p} / \bar{X}\right) * 100$

$\mathrm{GCV}=\left(\sqrt{ } \sigma^{2} \mathrm{~g} / \bar{X}\right) * 100$, where $\mathrm{PCV}=$ phenotypic coefficient of variation, $\sigma^{2} p=$ phenotypic variance, $\mathrm{GCV}=$ genotypic coefficient of variation, $\sigma^{2} \mathrm{~g}=$ genotypic variance and $\bar{X}=$ the grand mean for the trait considered.

\section{Phenotypic and genotypic correlation analysis}

Estimation of genotypic and phenotypic correlations was done based on components of variances estimated from analyses of variance and co-variances, respectively (Dabholkar, 1992). Phenotypic correlation coefficient (rp) $=$ Pcovxy $/ \sqrt{ }\left(\sigma^{2}\right.$ px. $\sigma^{2}$ py) and genotypic correlation coefficient $(\mathrm{rg})=\mathrm{Gcovxy} / \sqrt{ }\left(\sigma^{2} \mathrm{gx} \cdot \sigma^{2} \mathrm{gy}\right)$, where Pcovxy = phenotypic covariance between variables $\mathrm{x}$ and $\mathrm{y}$, Gcovxy = genotypic covariance between variables $x$ and $\mathrm{y}, \sigma^{2} \mathrm{gx}=$ genotypic variance for trait $\mathrm{X}, \sigma^{2} \mathrm{gy}=$ genotypic variance for trait $\mathrm{Y}, \sigma^{2} \mathrm{px}=$ phenotypic variance for trait $\mathrm{X}$ and $\sigma^{2}$ py=phenotypic variance for trait $\mathrm{Y}$.

The significance of phenotypic correlation coefficients was tested by the formula of Singh and Chaudhary (1996).

$\mathrm{t}^{\prime}=r_{p x y} * \sqrt{\frac{\mathrm{g}-2}{\left(1-r p^{2} x y\right)}}$

$t^{\prime}$ value was tested against the tabulated $t$-value for $(g-2)$ degree of freedom, where $g$ is the number of genotypes studied, whereas the significance of genotypic correlation coefficient was tested using the formula described by Robertson (1959) indicated as $\mathrm{t}^{\prime}=\frac{r \mathrm{~g}_{x y}}{S E_{\mathrm{gXY}}}$ and $\mathrm{SE}=\sqrt{\frac{1-\mathrm{rg}^{2} x y}{2 \mathrm{hx} * \mathrm{hy}}}$, where $h_{x}=$ heritability of trait $x, h_{y}=$ heritability of trait $y$, $g=$ number of genotypes and $r g x y=$ genotypic correlation coefficient. Thus, the calculated value is compared with tabulated ' $t$ ' value at $\mathrm{g}-2$ degrees of freedom at $5 \%$ and $1 \%$ level of significance.

Path-coefficient analysis and expected genetic advance (GA)

Path coefficient analysis was computed to partition the 
Table 2. Expected mean squares of some morphological and agronomic trait of barley genotypes grown at HARC, 2017.

\begin{tabular}{lcccccc}
\hline Trait & $\begin{array}{c}\text { Genotype } \\
(\mathbf{D f}=\mathbf{3 1 9})\end{array}$ & $\mathbf{R e p}(\mathbf{D f}=\mathbf{1})$ & $\begin{array}{c}\text { Block (rep) } \\
(\mathbf{D f}=\mathbf{3 8})\end{array}$ & $\begin{array}{c}\text { Error } \\
(\mathbf{D f}=\mathbf{2 8 1})\end{array}$ & $\mathbf{C V}$ & Mean \\
\hline DTE & $0.07 \mathrm{~ns}$ & $52.51 \mathrm{~ns}$ & $0.13^{*}$ & 0.07 & 4.49 & 5.71 \\
DTH & $155.30^{* *}$ & $954.41 \mathrm{~ns}$ & $4.37^{*}$ & 3.64 & 3.16 & 60.29 \\
DTM & $176.54^{* *}$ & $1154.69 \mathrm{~ns}$ & $17.15 \mathrm{~ns}$ & 16.37 & 3.97 & 101.90 \\
SC & $2.61^{* *}$ & $13.86 \mathrm{~ns}$ & $0.65^{* *}$ & 0.53 & 11.13 & 6.56 \\
N. Bloch & $4.28^{* *}$ & $12.80 \mathrm{~ns}$ & $0.87^{* *}$ & 0.79 & 17.57 & 5.05 \\
FTP & $0.77^{* *}$ & $16.83 \mathrm{~ns}$ & $0.32^{* *}$ & 0.28 & 11.80 & 4.48 \\
SLP & $1.73^{* *}$ & $110.30 \mathrm{~ns}$ & $0.48^{* *}$ & 0.39 & 8.72 & 7.18 \\
PH & $120.32^{* *}$ & $6177.08 \mathrm{~ns}$ & $31.39^{* *}$ & 23.19 & 4.60 & 104.79 \\
KPS & $266.79^{* *}$ & $626.79 \mathrm{~ns}$ & $27.78^{* *}$ & 25.24 & 14.67 & 34.23 \\
GY & $2400093.84^{* *}$ & $19932974.00 \mathrm{~ns}$ & $266094.00^{*}$ & 242424.00 & 17.76 & 2772.45 \\
BY & $22638721.16^{* *}$ & $741287174.00 \mathrm{~ns}$ & $4654534.00^{* *}$ & 34832580.00 & 20.27 & 9203.91 \\
HI & $0.01^{* *}$ & $0.36 \mathrm{~ns}$ & $0.03^{* *}$ & 0.003 & 16.52 & 0.32 \\
TKW & $68.41^{* *}$ & $252.17 \mathrm{~ns}$ & $5.61 \mathrm{~ns}$ & 5.61 & 6.53 & 36.25 \\
HLW & $36.15^{* *}$ & $302.71 \mathrm{~ns}$ & $10.87 \mathrm{~ns}$ & 10.85 & 5.42 & 60.76 \\
\hline
\end{tabular}

${ }^{*},{ }^{* *}=$ significant at 0.05 and 0.01 probability levels, $\mathrm{ns}=$ non-significant, $\mathrm{Df}=$ degree of freedom, $\mathrm{DTE}=$ Days to emergence, $\mathrm{DTH}=\mathrm{Days}$ to heading, DTM = Days to maturity, SC = scald, N.Bloch= Net bloch, FTP = Number of fertile tillers per plant, SLP = Spike length $(\mathrm{cm})$, $\mathrm{PH}=$ Plant height $(\mathrm{cm}), \mathrm{KPS}=$ Number of kernels per spike, $\mathrm{GY}=$ Grain yield $(\mathrm{kg} / \mathrm{ha}), \mathrm{BY}=$ Biomass Yield $(\mathrm{kg} / \mathrm{ha}), \mathrm{HI}=\mathrm{Seed}$ harvest index, $\mathrm{TKW}=$ Thousand kernel weight $(\mathrm{g}), \mathrm{HLW}=$ Hectolitre weight $(\mathrm{kg} / \mathrm{hl}), \mathrm{CV}=$ coefficient of variation.

correlation coefficients to direct and indirect effects of the characters on yield as illustrated by Dewey and Lu (1959) using the formula rij= Pij+ $\Sigma$ rikpkj; where, rij=mutual association between the independent character (i) and dependent character (j) as measured by the correlation coefficient, Pij=component of direct effects of the independent character (i) on dependent character (j) as measured by the path coefficient and $\Sigma$ rikpkj = summation of components of indirect effect of a given independent character (i) on the given independent character (j) via all other independent characters (k).

Genetic advance (GA) and genetic advance as percent of mean (GAM) were estimated with assumption that $5 \%$ of the genotypes was selected in accordance with the methods illustrated by Johnson et al. (1955).

$\mathrm{GA}=\mathrm{K} * \delta_{\mathrm{p}}{ }^{*} \mathrm{H}$ and $\mathrm{GAM}(\%)=\frac{\mathrm{GA}}{\bar{X}} * 100$

here, $\delta p=$ phenotypic standard deviation on mean basis, $\mathrm{H}=$ Heritability in a broad sense, $\mathrm{K}=$ selection differential (where $\mathrm{k}=2.06$ at $5 \%$ selection intensity), $\bar{X}=$ population mean of the quantitative character.

\section{RESULTS AND DISCUSSION}

\section{Analysis of variance for some morpho-agronomic traits}

The significant difference $(p<0.01)$ was observed among genotypes in all evaluated traits except days to emergence (Table 2). This indicated the existence of significant genetic variability among the evaluated genotypes, and this in turn provides ample scope for selecting superior landraces to improve productivity of barley.

From the three hundred and twenty genotypes, one hundred and twenty three of them gave higher grain yields than grand mean $(2772.45 \mathrm{~kg} / \mathrm{ha})$. Biomass yield exhibited the widest range (4341.17 to $18625.25 \mathrm{~kg} / \mathrm{ha})$ followed by grain yield (1402.32 to $6819.78 \mathrm{~kg} / \mathrm{ha})$, plant height $(74.37$ to $121.12 \mathrm{~cm})$ and days to heading $(41.49$ to 87.07 days). Genetic diversity of barley has also been reported by Seid et al. (2015) which indicates that grain yield exhibited the widest range (2258 to $6202 \mathrm{~kg} / \mathrm{ha}$ ) followed by biomass yield per plot (1483 to $2733 \mathrm{~g}$ ), plant height $(82.9$ to $118.1 \mathrm{~cm})$ and days to maturity $(110.3$ to 137 days).

Genotypes Shege, HB-1307, Acc-24970, Acc-233040A, HB -1966, HB - 42, Ardu 12-60B, Ahore 880/61, EH 1847 and HB -1963 produced significantly higher grain yield than other genotypes (Table 3 ). These high yielding genotypes were emerged after 5.7 days. Their days to heading were ranged from 60.6 days for genotype EH1847 to 80.1 days for genotype HB-42 and they were matured within 103.2 days for genotype $\mathrm{EH}-1847$ to 117.2 days for genotype Shege. Their plant height was ranged from $99.96 \mathrm{~cm}$ for genotype $\mathrm{EH}-1847$ to 117.32 $\mathrm{cm}$ for genotype Shege. The mean of best performing genotypes were showed that they were late for days to heading and maturity and taller than the remaining genotypes.

Severity of scald (SC) and net blotch (N. blotch) diseases was ranged from 2.78 for resistance genotype 
Table 3. Mean of traits of top ten yielding barley genotypes grown at HARC, 2017.

\begin{tabular}{|c|c|c|c|c|c|c|c|c|c|c|c|c|c|c|}
\hline Geno & DTE & DTH & DTM & SC & N.bloch & FTP & SLP & $\mathbf{P H}$ & KPS & GY & BY & $\mathrm{HI}$ & HLW & TKW \\
\hline HB -1963 & 5.71 & 68.75 & 109.95 & 3.81 & 4.90 & 4.37 & 6.75 & 100.02 & 28.20 & 5563.37 & 14406.20 & 0.35 & 67.56 & 45.43 \\
\hline $\mathrm{EH}-1847$ & 5.71 & 60.57 & 103.24 & 4.79 & 4.98 & 5.22 & 7.52 & 99.96 & 27.74 & 5571.93 & 14637.40 & 0.36 & 67.35 & 44.32 \\
\hline Ahore 880/61 & 5.72 & 71.10 & 116.68 & 4.22 & 5.04 & 4.51 & 4.94 & 107.71 & 52.53 & 5635.02 & 17296.00 & 0.33 & 62.90 & 44.51 \\
\hline Ardu 12-60B & 5.71 & 75.31 & 114.46 & 3.55 & 5.06 & 5.31 & 7.31 & 115.20 & 54.08 & 5800.80 & 18625.80 & 0.32 & 63.80 & 37.31 \\
\hline $\mathrm{HB}-42$ & 5.71 & 80.05 & 117.12 & 2.78 & 4.98 & 4.11 & 6.88 & 113.67 & 52.42 & 5856.52 & 14222.50 & 0.38 & 63.30 & 50.05 \\
\hline HB -1966 & 5.71 & 65.47 & 111.99 & 4.93 & 4.76 & 4.67 & 6.33 & 111.17 & 43.82 & 5927.98 & 15259.90 & 0.36 & 60.78 & 41.19 \\
\hline Acc-233040-A & 5.72 & 72.20 & 112.91 & 7.09 & 4.90 & 4.15 & 8.33 & 102.22 & 36.28 & 5951.85 & 15411.30 & 0.38 & 63.09 & 39.34 \\
\hline Acc-24970 & 5.71 & 65.50 & 112.19 & 4.73 & 5.39 & 4.68 & 5.99 & 106.91 & 43.49 & 6221.37 & 16511.50 & 0.35 & 62.47 & 43.03 \\
\hline HB-1307 & 5.71 & 65.51 & 111.30 & 3.00 & 5.04 & 5.28 & 6.87 & 109.09 & 44.66 & 6446.37 & 16392.70 & 0.36 & 64.21 & 41.19 \\
\hline Shege & 5.71 & 76.78 & 117.23 & 5.53 & 4.90 & 4.34 & 8.47 & 117.32 & 54.48 & 6819.78 & 18103.90 & 0.35 & 60.65 & 41.74 \\
\hline Mean of best & 5.71 & 70.12 & 112.71 & 4.44 & 4.99 & 4.66 & 6.94 & 108.33 & 43.77 & 5979.50 & 16086.74 & 0.35 & 63.61 & 42.81 \\
\hline Grand Mean & 5.71 & 60.29 & 101.90 & 6.56 & 5.05 & 4.48 & 7.18 & 104.79 & 34.23 & 2772.45 & 9203.91 & 0.32 & 60.76 & 36.25 \\
\hline Mean of Landrace & 5.71 & 59.70 & 101.12 & 6.69 & 5.06 & 4.48 & 7.19 & 105.01 & 33.98 & 2621.90 & 8913.21 & 0.32 & 60.42 & 35.65 \\
\hline Mean of released & 5.71 & 66.81 & 110.49 & 5.31 & 5.01 & 4.48 & 7.19 & 102.51 & 37.00 & 4406.30 & 12358.45 & 0.35 & 64.37 & 42.71 \\
\hline
\end{tabular}

Geno = Genotype, DTE = Days to emergence, DTH = Days to heading, DTM = Days to maturity, SC = scald, N.Bloch= Net bloch, FTP = Number of fertile tillers per plant(count), $\mathrm{SLP}=$ Spike length $(\mathrm{cm}), \mathrm{PH}=$ Plant height $(\mathrm{cm}), \mathrm{KPS}=$ Number of kernels per spike (count), GY= Grain yield $(\mathrm{kg} / \mathrm{ha}), \mathrm{BY}=\mathrm{Biomass} \mathrm{Yield}(\mathrm{kg} / \mathrm{ha}), \mathrm{HI}=\mathrm{Seed}$ harvest index, HLW= Hectolitre weight $(\mathrm{kg} / \mathrm{hl}), \mathrm{TKW}=$ Thousand kernel weight $(\mathrm{g})$

HB - 42 to 7.09 for susceptible genotype Acc233040-A and from 4.76 for genotype HB -1966 to 5.39 for genotype Acc-24970 respectively.

The number of fertile tillers per plant was ranged from 4.11 for genotype $\mathrm{HB}-42$ to 5.31 for genotype Ardu 12-60B with mean of 4.48, and the spike length per plant (SLP) was ranged from 4.94 $(\mathrm{cm})$ for genotype Ahore $880 / 61$ to $8.47(\mathrm{~cm})$ for genotype Shege with mean of $7.18(\mathrm{~cm})$. The number of kernels per spike was ranged from 27.74 for genotype EH -1847 to 54.48 for genotype Shege with mean of 34.23 , while the thousand kernel weight was ranged from $37.31(\mathrm{~g})$ for genotype Ardu 12-60B to 50.05 (g) for genotype HB-42 with mean of $36.25(\mathrm{~g}))$. The hectolitre weight of the grain of genotypes was ranged from $60.65(\mathrm{~kg} / \mathrm{hl})$ for genotype Shege to $67.56(\mathrm{~kg} / \mathrm{hl})$ for genotype HB -1963 with mean of $60.76(\mathrm{~kg} / \mathrm{hl})$.
High variability in biomass yield, grain yield and harvest index of best performing genotypes was also observed. The biomass yield was ranged from $14222.50(\mathrm{~kg} / \mathrm{ha})$ for genotype HB-42 to $18625.80(\mathrm{~kg} / \mathrm{ha})$ for genotype Ardu 12-60B with mean of $9203.91(\mathrm{~kg} / \mathrm{ha})$, and the grain yield was ranged from $5563.37(\mathrm{~kg} / \mathrm{ha})$ for genotype HB1963 to $6819.78(\mathrm{~kg} / \mathrm{ha})$ for genotype Shege with mean of $2772.45(\mathrm{~kg} / \mathrm{ha})$. Seed Harvest index was ranged from 0.32 for genotype Ardu 12-60B to 0.38 for genotype Acc-233040-A with mean of 0.32 (Tables 3).

The yield advantage of the best performing genotypes was ranged from $145.98 \%$ for genotypes Shege $(6819.78 \mathrm{~kg} / \mathrm{ha})$ to $100.66 \%$ for genotypes HB-1963 (5563.37 kg/ha) from grand mean (2772.45 kg/ha) (Table 3). The mean performance of landrace as compared to released varieties shows that landraces were earlier by
7.11 and 9.37 days for days to heading and maturity respectively. Girma et al. (2015) had reported similar finding that improve varieties were late for days to heading and maturity as compared to farmers varieties

The severity of scald also show that landrace were more susceptible to disease than released varieties, as this was due to released varieties that were developed with the objective of resistance to scald in hot spot areas like Holeta. Landraces were taller and had weak straw than released varieties. The variation among the mean of spike length of landrace and released varieties showed no difference among them. Girma et al. (2015) had similar finding that most of the farmers varieties were tall with weak stem, which was the common character of the local farmers varieties and improved varieties were relatively short with strong stem. Variation in spike length among the 
Table 4. Means, estimates of phenotypic $\left(\sigma^{2} \mathrm{p}\right)$, genotypic $\left(\sigma^{2} \mathrm{~g}\right)$, and environmental variance $\left(\sigma^{2} \mathrm{E}\right)$; phenotypic (PCV) and genotypic (GCV) coefficients of variations, broad sense heritability $\left(\mathrm{H}^{2}\right)$, genetic advance $(\mathrm{GA})$ and genetic advance as percentage of means (GAM) for various traits of barley genotypes grown at HARC, 2017.

\begin{tabular}{lcccccccccc}
\hline Trait & Mean & $\boldsymbol{\sigma e}^{2}$ & $\boldsymbol{\sigma}^{\mathbf{2}} \mathbf{g}$ & $\boldsymbol{\sigma}^{\mathbf{2}} \mathbf{p}$ & $\boldsymbol{\sigma}^{\mathbf{2}} \mathbf{E}$ & $\mathbf{H}^{\mathbf{2}}$ & $\mathbf{P C V}$ & $\mathbf{G C V}$ & $\mathbf{G A}$ & $\mathbf{G A M}$ \\
\hline DTH & 60.29 & 3.64 & 80.77 & 82.71 & 1.94 & 97.66 & 15.08 & 14.91 & 18.3 & 30.35 \\
DTM & 101.90 & 16.37 & 85.29 & 94.02 & 8.72 & 90.72 & 9.52 & 9.06 & 18.12 & 17.78 \\
SC & 6.56 & 0.53 & 1.10 & 2.89 & 1.79 & 38.10 & 25.91 & 15.99 & 1.33 & 20.34 \\
N.Bloch & 5.05 & 0.79 & 1.85 & 2.27 & 0.42 & 81.58 & 29.85 & 26.96 & 2.53 & 50.16 \\
FTP & 4.48 & 0.28 & 0.27 & 0.42 & 0.15 & 63.83 & 14.42 & 11.52 & 0.85 & 18.96 \\
SLP & 7.18 & 0.39 & 0.71 & 0.92 & 0.21 & 77.35 & 13.36 & 11.75 & 1.53 & 21.29 \\
PH & 104.79 & 23.19 & 51.73 & 64.08 & 12.35 & 80.73 & 7.64 & 6.86 & 13.31 & 12.70 \\
KPS & 34.23 & 25.24 & 120.77 & 133.38 & 12.62 & 90.54 & 33.74 & 32.10 & 21.54 & 62.92 \\
GY & 2772.45 & 242424.00 & 1160723.99 & 1291136.61 & 130412.61 & 89.90 & 40.98 & 38.86 & 2104.31 & 75.90 \\
BY & 9203.91 & 3483258.00 & 10682875.00 & 12625464.93 & 1942589.93 & 84.61 & 38.61 & 35.51 & 6193.44 & 67.29 \\
HI & 0.32 & 0.003 & 0.004 & 0.01 & 0.002 & 70.00 & 23.37 & 19.56 & 0.12 & 36.53 \\
TKW & 36.25 & 5.61 & 33.50 & 36.49 & 2.99 & 91.81 & 16.66 & 15.97 & 11.42 & 31.51 \\
HLW & 60.76 & 10.85 & 13.94 & 19.92 & 5.98 & 69.98 & 7.35 & 6.15 & 6.43 & 10.59 \\
\hline
\end{tabular}

$\mathrm{DTH}=$ Days to heading, DTM = Days to maturity, SC $=$ Scald, N.Bloch = Net bloch, FTP = Number of fertile tillers per plant (count), SLP = Spike length $(\mathrm{cm}), \mathrm{PH}=$ Plant height $(\mathrm{cm}), \mathrm{KPS}=$ Number of kernels per spike (count), GY= grain yield $(\mathrm{kg} / \mathrm{ha}), \mathrm{BY}=\mathrm{Biomass} Y \mathrm{Yeld}(\mathrm{kg} / \mathrm{ha}), \mathrm{HI}=\mathrm{Seed}$ harvest index, TKW= Thousand kernel weight $(\mathrm{g}), \mathrm{HLW}=$ Hectoliter weight $(\mathrm{kg} / \mathrm{hl})$.

farmers and improved varieties were small.

With regards to number of kernels per spike, landraces had lower number of seeds per spike than released varieties. The number of kernels per spike had relation with the final grain yield. The yield advantages of released varieties were 1.78 tones more than landraces. Biomass yield, harvest index, Hactoliter weight and thousand seed weight of released varieties were higher than landraces. Abtew et al. (2015) had similar finding that improved varieties that had higher grain yield than landrace. Acc-233040-A (5951.85kg/ha) and Acc-24970 $(6221.37 \mathrm{~kg} / \mathrm{ha})$ had better grain yield than recently released variety HB-1966 (5927.98 kg/ha).

\section{Phenotypic and genotypic variations}

For almost all studied traits, the genotypic $\left(\sigma^{2} \mathrm{~g}\right)$ and phenotypic $\left(\sigma^{2} \mathrm{p}\right)$ variance were larger than error variance $\left(\sigma^{2} e\right)$ (Table 4). This indicated that the number of blocks within replication used in evaluating these genotypes were adequate to give a better estimation for the error variance. The estimated phenotypic variance $\left(\sigma^{2} p\right)$ was higher than genotypic variance $\left(\sigma^{2} g\right)$. A wide range of $\sigma^{2} p$ was observed for biomass yield followed by grain yield and plant height, because these traits are quantitative traits which are highly influenced by environmental factors. The estimates of genotypic variance were higher than the corresponding environmental variance except for severity of scald diseases. This signified the existence of sufficient genetic variability among the studied genotypes for these traits (Table 4). Jaya (2017) had reported similar results which indicate that the estimates of phenotypic variance were higher than genotypic variance.

\section{Phenotypic (PCV) and genotypic (GVC) coefficients of variation}

GCV ranged from $6.15 \%$ for hectolitre weight to $38.86 \%$ for grain yield and PCV from $7.35 \%$ for hectolitre weight to $40.98 \%$ for grain yield (Table 4 ). The coefficients of variation revealed that, grain yield, biomass yield, net blotch disease, number of kernels per spike and scald disease had the highest variation. Such traits were the most indicative and responsive barley traits. Deshmukh et al. (1986) reported that genotypic and phenotypic coefficients of variation greater than $20 \%$ are considered as high. Jamshidi and Javanmard (2017) reported that grain yield, biological yield and harvest index had the highest rate of variation. Therefore these traits are essential for selecting superior barley genotypes. However, traits hectolitre weight and plant height had the least rate of variation and are not much suitable traits for selecting superior barley genotypes. The difference between PVC and GVC for scald diseases, number of kernels per spike, harvest index and biomass yield was large. This showed that the influence of the environment on their expression was large. The difference between PVC and GVC was small for days to heading and maturity, thousand-kernel weight and plant height. This indicated the existence of enormous inherent variability that remain less affected by environment, and useful for indirect selection of genotypes in improving barley genotypes. Jaya (2017) reported similar findings of GVC and PVC for barley genotypes, which indicates high estimates of variation that were observed for number of effective tillers per plant, spike length and biological yield. Low GCV and PCV were observed for days to flowering and maturity. 


\section{Broad sense heritability and genetic advance}

Broad sense heritability was ranged from 38 for Scald disease to $98 \%$ for days to heading. Highest broad sense heritability was observed for days to heading, days to maturity, thousand-kernel weight, grain yield, scald diseases, number of kernels per spike, biomass yield, number of fertile tillers per plant, hectolitre weight, spike length, seed harvest index, plant height and Net blotch diseases.

Genetic advance as percent of mean (GAM) was estimated in order to determine the relative merits of different characters that could be further utilized in the selection program of crop improvement. According to Johnson et al. (1955), genetic advance as percent of mean was categorized as high ( $>20 \%)$, moderate (10 to $20 \%$ ) and low (0 to 10). High GAM were obtained from grain yield, biomass yield, net blotch diseases, number of kernels per spike, harvest index, thousand-kernel weight, days to heading, spike length and scald diseases, while moderate were obtained for fertile tillers per plant, days to maturity, plant height and hectolitre weight (Table 4).

Relative comparison of heritability along with genetic advance as percent of mean of the traits indicated that days to heading, days to maturity, thousand kernel weight, grain yield, scald diseases, number of kernels per spike, biomass yield, number of fertile tillers per plant, hectolitre weight, spike length, harvest index, plant height and net blotch diseases had high heritability estimates along with high genetic advance as percent of mean. Jalal (2012) had reported that number of kernels per main spike, grain yield, biological yield, plant height, thousand kernels weight and number of fertile tillers per plant had high heritability accompanied with high genetic advance. Jaya (2017) also indicated that plant height, number of effective tillers, spike length, biological yield and grain yield had high heritability estimates along with high genetic advance as percent of mean.

\section{Phenotypic and genotypic correlation of yield with other traits}

Genotypic correlation coefficient values were greater for most of the traits than their corresponding phenotypic correlation coefficient values, indicating the inherent association of the traits.

Grain yield had positive and highly significant phenotypic correlation with days to heading, days to maturity, number of kernels per spike, biomass yield, thousand kernel weight and hectolitre weight. Additionally, grain yield had significant correlation with fertile tillers per plant, plant height, harvest index and spike length. Similarly at genotypic level, days to heading, days to maturity, number of kernels per spike, biomass yield, thousand kernel weight and hectolitre weight exhibited positive and highly significant correlation with grain yield. Plant height, harvest index and spike length exhibited positive and significant genotypic correlation with grain yield (Table 5). This indicates that selecting for higher values of these traits could lead to grain yield improvement of barley. Zerihun (2007) reported that grain yield per plot had positive and highly significant association with days to heading, days to maturity, number of kernels per spike, biomass yield, harvest index and thousand kernel weight at both phenotypic and genotypic level. Jalal (2012) and Temesgen (2014) had also similar findings.

\section{Genotypic path coefficient analysis}

Genotypic path coefficient analysis revealed that biomass yield followed by seed harvest index had high and positive direct effects on grain yield. In addition to this, their association with grain yield was highly significant and positive (Table 6). Positive association and direct effect suggested that these traits were good contributors of grain yield and significantly help as selection criteria in barley breeding programs. The minimum direct effect was exerted by plant height, spike length, thousand kernel weight, hectolitre weight, days to maturity and number of kernels per spike and negative direct effect was exerted by days to heading and scald disease; but, had positive association with grain yield except scald disease at genotypic levels. Zerihun (2007) had similar report which stated that positive direct effect on grain yield per plot was exerted by harvest index per plot $(0.65)$ followed by biomass yield per plot (0.64). Days to maturity, Days to heading, Thousand kernel weight, Hectolitre weight, Spike length and Number of kernels per spike (0.26) and scald disease $(-0.54)$ and Seed harvest index $(-0.38)$ had exerted positive and negative indirect effects respectively on grain yield through biomass yield.

\section{CONCLUSIONS}

Studying the genetic variability of plant germplasm, association of traits with grain yield and their heritability is the first step in plant breeding programs to select plants having the required characters. In this line, 320 barley genotypes were evaluated and the analysis of variance showed that there were significant differences among genotypes for all traits except days to emergence, which is mainly influenced by available soil moisture. Better phonological, yield and yield components responses of barley were observed from genotypes; Shege, HB-1307, Acc-24970, Acc-233040-A, HB -1966, HB - 42, Ardu 1260B, Ahore 880/61, EH -1847 and HB -1963. Genotypic and phenotypic coefficients of variation were ranged from $6.15 \%$ for hectolitre weight to $38.86 \%$ for grain yield and from $7.35 \%$ for hectolitre weight to $40.98 \%$ for grain yield, respectively. Broad sense heritability was in the range of 
Table 5. Estimates of Phenotypic (below diagonal) and genotypic (above diagonal) correlation coefficients among various traits of barley genotypes grown at HARC, 2017.

\begin{tabular}{|c|c|c|c|c|c|c|c|c|c|c|c|c|c|}
\hline Trait & DTH & DTM & SC & N.Bloch & FTP & $\mathbf{P H}$ & SLP & KPS & GY & BY & $\mathrm{HI}$ & TKW & HLW \\
\hline DTH & & $0.89^{* *}$ & $-0.47^{* *}$ & $-0.06 \mathrm{~ns}$ & $-0.14^{*}$ & $0.05 \mathrm{~ns}$ & $0.14^{*}$ & $0.50^{* *}$ & $0.51^{* *}$ & $0.62^{\star *}$ & $-0.19^{\star *}$ & $0.36^{* *}$ & $0.37^{* *}$ \\
\hline DTM & $0.86^{\star *}$ & & $-0.46^{\star \star}$ & $-0.02 \mathrm{~ns}$ & $-0.12^{*}$ & $-0.01 \mathrm{~ns}$ & $0.08 \mathrm{~ns}$ & $0.52^{\star \star}$ & $0.59^{\star *}$ & $0.65^{\star \star}$ & $-0.14^{*}$ & $0.34^{\star *}$ & $0.38^{* *}$ \\
\hline SC & $-0.45^{\star *}$ & $-0.43^{\star *}$ & & $0.05 \mathrm{~ns}$ & $-0.07 \mathrm{~ns}$ & $-0.1 \mathrm{~ns}$ & -0.02 ns & $-0.26^{\star *}$ & $-0.59^{\star *}$ & $-0.53^{* *}$ & $-0.02 \mathrm{~ns}$ & $-0.32^{\star *}$ & $-0.25^{\star *}$ \\
\hline N.Bloch & -0.03 ns & $-0.01 \mathrm{~ns}$ & $0.01 \mathrm{~ns}$ & & $0.07 \mathrm{~ns}$ & $0.05 \mathrm{~ns}$ & $-0.01 \mathrm{~ns}$ & -0.03 ns & -0.03 ns & $0.01 \mathrm{~ns}$ & $-0.05 \mathrm{~ns}$ & -0.02 ns & $-0.02 \mathrm{~ns}$ \\
\hline FT & $-0.08^{*}$ & -0.06 ns & $-0.10^{*}$ & 0.02 ns & & $0.11^{*}$ & $0.25^{\star \star}$ & $-0.30^{\star *}$ & 0.09 ns & $0.16^{*}$ & $-0.13^{*}$ & $0.16^{*}$ & $0.08 \mathrm{~ns}$ \\
\hline PHT & 0.07 ns & $0.03 \mathrm{~ns}$ & $-0.13^{*}$ & $0.04 \mathrm{~ns}$ & $0.17^{*}$ & & $0.32^{* *}$ & 0.09 ns & $0.14^{*}$ & $0.22^{\star \star}$ & $-0.17^{*}$ & $0.11^{*}$ & $-0.04 \mathrm{~ns}$ \\
\hline SL & $0.16^{\star *}$ & $0.12^{*}$ & -0.07 ns & $0.01 \mathrm{~ns}$ & $0.27^{\star \star}$ & $0.38^{\star \star}$ & & $-0.26^{\star \star}$ & $0.13^{*}$ & $0.30^{\star *}$ & $-0.30^{* *}$ & $0.40^{* *}$ & $0.22^{* *}$ \\
\hline KPS & $0.47^{\star *}$ & $0.49^{\star *}$ & $-0.24^{\star \star}$ & $-0.02 \mathrm{~ns}$ & $-0.23^{\star \star}$ & $0.14^{*}$ & $-0.15^{\star}$ & & $0.31^{* *}$ & $0.26^{\star \star}$ & $0.04 \mathrm{~ns}$ & $-0.38^{\star *}$ & $-0.11^{*}$ \\
\hline YLD & $0.49^{* *}$ & $0.56^{\star *}$ & $-0.53^{\star \star}$ & $-0.02 \mathrm{~ns}$ & $0.10^{*}$ & $0.18^{*}$ & $0.15^{*}$ & $0.31^{* *}$ & & $0.82^{\star \star}$ & $0.18^{* *}$ & $0.48^{\star *}$ & $0.38^{* *}$ \\
\hline BM & $0.58^{* *}$ & $0.61^{* *}$ & $-0.47^{* *}$ & $0.01 \mathrm{~ns}$ & $0.17^{* *}$ & $0.28^{* *}$ & $0.33^{* *}$ & $0.25^{\star *}$ & $0.79^{* *}$ & & $-0.38^{* *}$ & $0.48^{* *}$ & $0.37^{* *}$ \\
\hline $\mathrm{HI}$ & $-0.2^{\star \star}$ & $-0.17^{*}$ & $0.04 \mathrm{~ns}$ & $-0.03 \mathrm{~ns}$ & $-0.16^{\star}$ & $-0.23^{\star \star}$ & $-0.35^{\star \star}$ & $0.01 \mathrm{~ns}$ & $0.13^{*}$ & $-0.46^{\star *}$ & & $-0.01 \mathrm{~ns}$ & $-0.03 \mathrm{~ns}$ \\
\hline TKW & $0.32^{* *}$ & $0.30^{\star *}$ & $-0.26^{* *}$ & -0.02 ns & $0.10^{*}$ & $0.07 \mathrm{~ns}$ & $0.28^{\star *}$ & $-0.36^{\star *}$ & $0.44^{\star *}$ & $0.39^{\star *}$ & $0.05 \mathrm{~ns}$ & & $0.51^{* *}$ \\
\hline HLW & $0.31^{* *}$ & $0.32^{* *}$ & $-0.19^{* *}$ & $-0.05 \mathrm{~ns}$ & 0.02 ns & $-0.07 \mathrm{~ns}$ & $0.11^{*}$ & $-0.11^{*}$ & $0.32^{* *}$ & $0.27^{\star *}$ & $0.04 \mathrm{~ns}$ & $0.50^{* *}$ & \\
\hline
\end{tabular}

${ }^{* * *}=$ significant at 0.05 and 0.01 levels of probability, respectively, $\mathrm{ns}=$ non-significant, DTH = Days to heading, DTM $=$ Days to maturity, SC $=\mathrm{scald}, \mathrm{N} . \mathrm{bloch}=\mathrm{Net}$ Bloch, FTP $=$ Number of fertile tillers per plant(count), SLP $=$ Spike length $(\mathrm{cm}), \mathrm{PH}=$ Plant height $(\mathrm{cm}), \mathrm{KPS}=$ Number of kernels per spike (count), GY= Grain yield $(\mathrm{kg} / \mathrm{ha})$, BY $=$ Biomass Yield(kg/ha), $\mathrm{HI}=$ Seed harvest index, TKW = Thousand kernel weight $(\mathrm{g}), \mathrm{HLW}=$ Hectolitre weight $(\mathrm{kg} / \mathrm{hl})$.

Table 6. Estimates of genotypic path coefficient analysis among various traits of barley genotypes grown at HARC, 2017.

\begin{tabular}{lccccccccccc}
\hline & DTH & DTM & SC & PHT & SLP & KPS & BY & HI & TKW & HLW & rg \\
\hline DTH & $\underline{\mathbf{- 0 . 1 1}}$ & 0.03 & 0.02 & 0.00 & 0.00 & 0.03 & 0.62 & -0.10 & 0.01 & 0.01 & $0.51^{* *}$ \\
DTM & -0.10 & $\underline{\mathbf{0 . 0 4}}$ & 0.02 & 0.00 & 0.00 & 0.03 & 0.66 & -0.08 & 0.01 & 0.01 & $0.59^{* *}$ \\
SC & 0.05 & -0.02 & $\underline{\mathbf{- 0 . 0 5}}$ & 0.00 & 0.00 & -0.02 & -0.54 & -0.01 & 0.00 & -0.01 & $-0.59^{* *}$ \\
PHT & -0.01 & 0.00 & $\mathbf{0 . 0 0}$ & $\underline{\mathbf{0 . 0 1}}$ & 0.00 & 0.01 & 0.22 & -0.09 & 0.00 & 0.00 & $0.14^{*}$ \\
SLP & -0.02 & 0.00 & 0.00 & 0.00 & $\underline{\mathbf{0 . 0 1}}$ & -0.02 & 0.31 & -0.17 & 0.01 & 0.01 & $0.13^{*}$ \\
KPS & -0.06 & 0.02 & 0.01 & 0.00 & 0.00 & $\underline{\mathbf{0 . 0 6}}$ & 0.26 & 0.02 & -0.01 & 0.00 & $0.31^{* *}$ \\
BY & -0.07 & 0.02 & 0.02 & 0.00 & 0.00 & 0.02 & $\underline{\mathbf{1 . 0 1}}$ & -0.21 & 0.01 & 0.01 & $0.82^{* *}$ \\
HI & 0.02 & -0.01 & 0.00 & 0.00 & 0.00 & 0.00 & -0.38 & $\underline{\mathbf{0 . 5 5}}$ & 0.00 & 0.00 & $0.18^{* *}$ \\
TKW & -0.04 & 0.01 & 0.01 & 0.00 & 0.00 & -0.02 & 0.48 & 0.00 & $\underline{\mathbf{0 . 0 2}}$ & 0.02 & $0.48^{* *}$ \\
HLW & -0.04 & 0.01 & 0.01 & 0.00 & 0.00 & -0.01 & 0.38 & -0.01 & 0.01 & $\underline{\mathbf{0 . 0 3}}$ & $0.38^{* *}$ \\
\hline
\end{tabular}

${ }^{*},{ }^{* *}=$ significant at 0.05 and 0.01 of probability levels, respectively, DTH = Days to heading, DTM = Days to maturity, SC = scald, SLP $=$ Spike length $(\mathrm{cm}), \mathrm{PHT}=$ Plant height $(\mathrm{cm}), \mathrm{KPS}=$ Number of kernels per spike (count), BY $=$ Biomass Yield $(\mathrm{kg} / \mathrm{ha}), \mathrm{HI}=$ Seed harvest index, TKW= Thousand kernel weight $(\mathrm{g}), \mathrm{HLW}=$ Hectolitre weight $(\mathrm{kg} / \mathrm{hl}), \mathrm{rg}=\mathrm{Genotypic}$ correlation coefficient. 
38 for scald diseases to $98 \%$ for days to heading, and the highest genetic advances as percent of means were obtained from grain yield, biomass yield and number kernels per spike.

Both phenotypic and genotypic correlations of grain yield with days to heading and maturity, number of kernels per spike, biomass yield, thousand kernel weight, hectolitre weight, plant height and harvest index were positive and significantly high. Based on the results obtained, it is concluded that the studied barley genotypes have high genetic variation in the studied traits, and the significantly correlated traits with grain yield are good yield contributors. Thus, they could be used as indirect plant selection criteria for grain yield improvement of the studied barley genotypes.

\section{ACKNOWLEDGEMENT}

The authors are grateful Ethiopian Institute of Agricultural Research (EIAR) for its financial support for this research.

\section{REFERENCES}

Abebe D (2006). Regional strategy for the ex situ conservation of plant genetic resources: Eastern Africa. Eastern Africa Plant Genetic Resources Network (EAPGRN).

Abtew WG, Berhane L, Bettina IGH, Karl JS (2015). Ethiopian barley landraces show higher yield stability and comparable yield to improved varieties in multi-environment field trials. Plant Breed. Crop Sci. 7(8):275-291.

Badr A, Müller K, Scha"fer-Pregl R, El Rabey H, Effgen S, Ibrahim HH, Pozzi C, Rohde W, Salamini F (2000). On the origin and domestication history of barley (Hordeum vulgare). Mol. Biol. Evol. 17:499-510.

Berhane L, Hailu G, Fekadu A (1996). Barley production and research. In G. Hailu and J. van Leur (eds.). Barley Research in Ethiopia. Past work and future prospects. Proceedings of the First Barley Review work shop, 16- 19 October 1993, Addis Ababa: IAR/ICARDA.

CSA (Central Statistical Agency) (2018). Agricultural sample survey: area and production of major crops, meher season. Vol. I. Addis Ababa, Ethiopia.

Dabholkar AR (1992). Elements of Biometrical Genetics. Concept Publishing Company, New Delhi 110059. p. 431.

Deshmukh SN, Basu MS, Reddy PS (1986). Genetic variability, characters associations and path coefficients of quantitative traits in Virginia bunch varieties of groundnut. Indian J. Agric. Sci. 56: 515518.

Dewey DR, Lu KN (1959). A correlation and path coefficient analysis of components of crested wheat grass seed production. Agron. J. 51:515-518.

Ellis R, Foster B, Handley L, Gordon D, Russell J, Powell W (2000). Wild barley: a source of genes for crop improvement in the $21^{\text {st }}$ century. Exp. Bot. 51:9-17.

FAO (food and agriculture organization for United Nations) (2016). Food balance sheets. Faostat. Rome (http://www.fao.org/faostat/en/\#data/QC/visualize) (Accessed on 12 February 2018).
Girma M, Firew M, Berhane L (2015). Performance of farmers' and improved varieties of barley for yield and seed quality. Plant breed. Crop Sci. 7(4):107-124.

Harlan JR (1968). On the origin of barley. In Barley: Origin, Botany, Culture, Winter Hardiness, Genetics, Utilization\& Pests, USDA Agricultural Handbook 338:12-34.

Jalal A (2012). Assessment of genetically diverse international barley germplasm for development of food product applications. PhD thesis, Southern Cross University, Lismore, NSW. p. 204.

Jamshidi A, Javanmard HR (2017). Evaluation of barley (Hordeum vulgare L.) genotypes for salinity tolerance under field conditions using the stress indices. Ain Shams Eng.

Jaya S, Shekhawat AS, Sunita K (2017). Genetic variation and heritability studies for yield and yield components in barley genotypes under normal and limited moisture conditions. Pharmacogn. Phytochem. 6(4):233-235.

Johnson HW, Robinson HE, Comstock RE (1955). Estimates of genetic and environmental variability in soybean. Agron. 47:314-318.

Muluken B (2013). Study on malting barley genotypes under diverse agro ecologies of north western Ethiopia: Adet Agricultural Research Centre, p. O. Box 08, Bahirdar, Ethiopia.

Nevo E (1992). Origin, evolution, population genetics and resources for breeding of wild barley, Hordeum spontaneum, in the fertile crescent. Chapter 2. In: PR Shewry, ed. Barley genetics, biochemistry, molocular biology and biotechnology. C.A.B International, Wallingford, Oxon. pp. 19-43.

Robertson A (1959). The sampling variance of the genetic correlation coefficient. Biometrics, 15:469-485.

Saari EE, Prescott JM (1975). A scale for appraising the foliar intensity of wheat diseases. Plant Disease Reporter 59:377-380.

Seid E, Eleni S, Faris H (2015). Evaluation of genetic diversity in barley (Hordeum vulgare L.) from Wollo high land areas using agromorphological traits and hordein. Acad. J. 14(22):1886-1896.

Singh RK, Chaudhary BD (1996). Biometrical methods in quantitative genetic analysis. Kalayani Publishers, India. p 318.

Temesgen D (2014). Soil acidity-induced land use/cover change and management systems on soil quality parameters in the central highlands of Ethiopia. PhD Thesis. Sustainable Forest Management Research Institute University of Valladolid-INIA. Spain. pp. 170-173.

USDA (United State Department of Agriculture) (2015). Global Agricultural information Network. Grain and Feed annual Report.

Vavilov NI (1951). The origin, variation, immunity and breeding of cultivated plants. Chron. Bot. 13:1-366.

Zerihun $\mathbf{J}$ (2007). Variability and Association of Yield and Yield-related Traits in Some Barley (Hordeum vulgare I.) Landraces and Crosses. Msc. Thesis. Haramaya University. p. 43.

Zohary D, Hopf M (1993). Domestication of plants in the old world. The origin and spread of cultivated plants in West Asia, Europe and the Nile Valley. Clarendon Press, Oxford. 